\title{
Be yourself... but don't be a wimp! Advice Literature in the USSR and Gender Roles in Contemporary Ukrainian Books for Girls and Boys
}

Be yourself. . . but don't be a wimp! Advice Literature in the USSR and Gender Roles in Contemporary Ukrainian Books for Girls and Boys. Even though advice literature for children has a long history in Western Europe and the USA, it became popular in all post-Soviet states only in the late 1980s. Still, advice literature for adults played an important role in the formation of gender stereotypes in the USSR. After the collapse of communism manuals for different age groups including advice on etiquette, manners, sex, and looks flooded bookstores and libraries in all post-Soviet states. The essay examines Ukrainian advice literature for boys and girls and the influence gender stereotypes it promotes have on children. Comparing two popular sets of contemporary handbooks for boys and girls, the author shows that they reinforce hegemonic patriarchal gender roles based on inequality and sexism.

Keywords: girlhood, boyhood, Ukraine, advice literature, gender stereotypes

Будьте собой... только не будьте слабаками! Гендерные стереотипы в украинской справочной литературе для девочек и мальчиков. Эссе включает в себя изучение стереотипного описания гендерных ролей в украинской литературе. Материалом для исследования послужили четыре книги, опубликованные за последние пять лет. Рассматривая нормы и модели поведения, представленные в этих книгах, автор показывает роль таких книг в постсоветском возрождении патриархальных норм. Автор демонстрирует, что в украинских справочниках для мальчиков и девочек дети представлены как товар, на который может возрастать или падать спрос в обществе.

Ключевые слова: девичество, детство, Украина, справочная литература, гендерные стереотипы

* Address: ul. Pocztowa 9, 53-313 Wrocław. E-mail: mateusz.swietlicki@uwr.edu.pl. 
We teach girls to shrink themselves, to make themselves smaller. We say to girls, you can have ambition, but not too much. You should aim to be successful, but not too successful. Otherwise, you would threaten the man. Because I am female, I am expected to aspire to marriage. I am expected to make my life choices always keeping in mind that marriage is the most important. Now marriage can be a source of joy and love and mutual support but why do we teach girls to aspire to marriage and we don't teach boys the same? We raise girls to see each other as competitors not for jobs or accomplishments, which I think can be a good thing, but for the attention of men. [...] We spend too much time telling girls that they cannot be angry or aggressive or tough, which is bad enough, but then we turn around and either praise or excuse men for the same reasons. All over the world, there are so many magazine articles and books telling women what to do, how to be and not to be, in order to attract or please men. [...] We teach girls shame. "Close your legs. Cover yourself." We make them feel as though being born female they're already guilty of something. ${ }^{1}$

Chimamanda Ngozi Adichie

In her well-known speech "We Should All Be Feminists" (2012), Nigerian author Chimamanda Ngozi Adichie's focuses on the damaging gender stereotypes imposed on children from the earliest stages of development and points out to the role advice literature plays in that process. While Ngozi Adichie directly mentions popular magazines and books for women, bookstores all over the world are cramped with manuals for children, which teach them what it means to be "a real boy" and "a real girl" and what to do in order to increase their demand in society.

Even though advice literature for children has a long history in Western Europe and the USA, it became popular in all post-Soviet states only in the late 1980 s. $^{2}$ Still, advice literature for adults played an important role in the formation of gender stereotypes in the USSR. After the collapse of communism manuals for different age groups including advice on etiquette, manners, sex, and looks flooded bookstores and libraries in all post-Soviet states. In this essay, I want to focus on Ukrainian advice literature for boys and girls and the influence gender stereotypes it promotes have on children. Comparing two popular sets of contemporary handbooks for boys and girls - A 100\% Girl [Дівчинка на 100\%, 2016] vs. A 100\% Bоу [Хлопчик

${ }^{1}$ C. Ngozi Adichie, We should all be feminists, https://www.youtube.com/watch?v=hg3umXU_ qWc (access: 15.07.2017). The speech gained widespread media exposure when it was heavily sampled by Beyoncé in her hit song "Flawless."

2 A. Lanoux, "Laundry, potatoes, and the everlasting soul: Russian advice literature for girls after communism," The Russian Review July 2014, 73, p. 405. 
на всі 100\%, 2016] and Encyclopaedia for Girls [Енциклопедія для дівчаток, 2016] vs. Encyclopaedia for Boys [Енциклопедія для хлопчиків, 2016] — I show that they reinforce hegemonic patriarchal gender roles based on inequality and sexism.

\section{Children and Gender Roles}

Gender is constructed from birth, as children are born into certain discourse practices, which identify certain roles and types of behaviour as either male or female. ${ }^{3}$ Even the youngest children perform certain gender roles which are constructed throughout their schooling. ${ }^{4}$ Nowadays the most common explanation for gender differences is the one which treats them as social constructions with the recognition that there are certain biological differences upon which gender is formed. ${ }^{5}$ Nevertheless, some scholars argue that "the centre of the struggle is the common-sense assumption that there is a natural way for girls, boys, women and men to be." ${ }^{\text {Ha- }}$ bitual practices in society further reinforce these stereotypes. According to Elaine Millard, "actions performed in similar contexts on a daily basis have the effect of reinforcing the dominant (patriarchal) structures of society and uniformity of gendered behaviour."'

Usually children take up predictable positions in relation to their own gender identities. Still, one may argue that "children are non-agents, at times unwillingly or

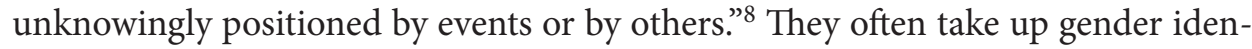
tities and treat them in a binary opposition, which, in accordance with Derrida's theory create two categories - ascendant and subordinate. In such dualistic pairs, as 'girls' and boys', boys are frequently treated as the ascendant category and girls as the subordinate category. ${ }^{9}$ Maybe that is why "girls are often willing to take on male identities and incorporate the wishes of boys in their role-play, but boys are generally

${ }^{3}$ See J. Solsken, Literacy, Gender, and Work in Families and in School, Norwood 1983; E. Millard, Differently Literate: The Schooling of Boys and Girls, London 1997.

${ }^{4}$ See J. Whyte, Beyond the Wendy House: Sex Role Stereotyping in Primary Schools, York 1983; B. Davies, "Agency as a form of discursive practice: A classroom scene observed," British Journal of Sociology of Education, vol. 11, 1990 , no. 3, pp. 341-61; B. Thorne, Gender Play: Girls and Boys in School, Buckingham 1993; C. Weedon, Feminist Practice and Poststructuralist Theory, Oxford 1987.

5 J. Marsh, E. Millard, Literacy and Popular Culture. Using Children's Culture in the Classroom, London 1995, p. 33.

${ }^{6}$ C. Weedon, op. cit., p. 98.

${ }^{7}$ E. Millard, op. cit., p. 21.

${ }^{8}$ J. Marsh, E. Millard, op. cit., p. 33.

9 According to Davis, "They take their category membership to be normal, and normative, and those located in the other category to be marked by their difference. People inhabiting ascendant categories such as male, heterosexual, white, middle-class, able-bodied, adult or sane, often wonder what all the fuss is about, and doubt even the relevance of their own category membership in determining who they might be." B. Davies, "Constructing and deconstructing masculinities through critical literacy," Gender in Education, vol. 9, 1997, no. 1, p. 13. 
unwilling to demonstrate a similar level of adaptability." ${ }^{10}$ Moreover, boys are also disadvantaged by the hegemonic model of masculinity. ${ }^{11}$ Even though performing dominant masculinity provides men with power, many boys grow up to be men who do not fit into its tight frames. ${ }^{12}$

\section{Advice Literature in the USSR}

Despite the fact that the ideological equality of the sexes in the Soviet Union was just a myth, as women worked professionally and performed the traditional roles of wives and mothers, men, on the other hand, "defended socialism" and were passive husbands and fathers, ${ }^{13}$ the belief that communism ascribed feminine qualities to men and masculine to women, consequently reversing gender roles remained so convincing that during the socio-political transition in the 1990s of traditional femininity and masculinity, roles were to be restored in Eastern Europe. ${ }^{14}$ Men were supposed to be the sole breadwinners and their stay-at-home-wives became symbols of their high social status. ${ }^{15}$ While the post-communist transition was a period of an intensified re-emergence of traditional femininity and masculinity, Catriona Kelly demonstrates that they had already started to slowly infiltrate the identity of the New Soviet Man as homo sovieticus identity as early as the 1950s, often through advice literature. Because The Communist Party tried to bring together the ideology and the citizens' growing desire for material things, The $22^{\text {nd }}$ Congress, which was held from 17 to 31 October 1961, attempted "to suggest harmony between communist ideology and material comfort." ${ }^{16}$ After Stalin's death not only did the production of

${ }^{10}$ See B. Davies, op. cit.; B. Davies, "The gender trap: a feminist post-structuralist analysis of primary school children's talk about gender," Journal of Curriculum Studies, vol. 24, 1992, no. 1, pp. 1-25; E. Jordan, "Fighting boys and fantasy play: the construction of masculinity in the early years of school," Gender and Education, vol. 7, 1995, no. 1, pp. 69-86; G. MacNaughton, "Who's got the power? Rethinking gender equity strategies in early childhood," International Journal of Early Years Education, vol. 5, 1997, no. 1, pp. 57-66.

11 Usually still based on the four rules described by Robert Brannon in 1976: "No sissy stuff!", "Be a big wheel", "Be a sturdy oak", and "give 'em hell". R. Brannon, "The male sex role: Our culture's blueprint for manhood and what it's done for us lately", [in:] The Forty-Nine Percent Majority: The Male Sex Role, ed. D. David, R. Brannon, Reading MA 1976, pp. 1-48.

12 See: R.W. Connell, J.W. Messerschmidt, "Hegemonic masculinity: Rethinking the concept", Gender \& Society, December 2005, vol. 19, no. 6, pp. 829-859.

13 Ж. Чернова, “Модель “советского” отцовства: дискурсивные предписания," [в:] Е. Здравомыслова, А. Темкина (ред.), Российский гендерньй порядок: социологический поход: Коллективная монограбия, Санкт-Петербург 2007, pp. 138-168.

14 I. Novikova, "Soviet and post-Soviet masculinities: after men's wars in women's memories," [in:] Male roles, masculinities and violence: a culture of peace perspective, eds. I. Breines, R. Connell, and I. Eide, UNESCO publishing, Paris 2000, p. 119.

15 C. Kelly, Refining Russia: Advice Literature, Polite Culture, and Gender from Catherine to Yeltsin, Oxford 2001, p. 374.

16 Ibid., p. 314.

Miscellanea Posttotalitariana Wratislaviensia 7, 2017

(C) for this edition by CNS 
consumer goods increase but also the "shadow economy" - black-market trade in Western products - and, consequently, corruption grew. ${ }^{17}$

Kelly points out that books on basic hygiene and self-education had been published before the 1950s, but all pre-revolutionary etiquette books were banned in 1918. This changed in the 1950s when the Communist Party decided that all Soviet men and women were supposed to have good taste in manners and use refined, yet ideological speech. ${ }^{18}$ Two types of advice books were introduced - literature on behaviour and etiquette, and housekeeping manuals. ${ }^{19}$ The first book about behaviour was published in 1954, several books about household management followed. ${ }^{20}$ While though as early as 1956 readers of "Komsomolskaya Pravda" complained about their dissatisfaction with harsh living conditions in places like the Donbass, quite often these new manuals included recipes for fancy dishes made of products which were not available for typical citizens and promoted a fantasy vision of the perfect Soviet world. ${ }^{21}$ Because the Khrushchev and Brezhnev era placed emphasis on the printed word, most titles had high print-runs and were a great form of propaganda. ${ }^{22}$ Most included information on women's health, beauty, sewing, as well as tips on "the protection of maternity and childhood", along with the old set of Soviet values. ${ }^{23}$ Moreover, magazines for women like "Rabotnitsa" and "Krest'yanka" popularized similar patterns of behaviour.

Advice literature promoted polarized gender roles, men as strong patriarchs and women as fragile housekeepers who were supposed to always remember about etiquette and behaviour. The most popular handbook, House Management, was published in 1957. Interestingly, it was similar to the most popular pre-Soviet handbook, Elena Molokhovet's A Gift to Young Housewives (1861). ${ }^{24}$ The book consists of 13 sections on various things such as domestic hygiene, cooking and preserving, sewing, upbringing of children, etiquette, hygiene, and skin care for women. ${ }^{25}$ Even though House Management includes chapters about health, they are devoted solely to women's issues. Kelly points out that in order to be perceived as cultural, men only had to treat women well in public - the private sphere was not important. ${ }^{26}$ Women, on the other hand, constantly had to be "symbols of refinement" and several restrictions were imposed upon their behaviour. ${ }^{27}$ Later books, such as V. A. Sysenko's Family Conflicts (1983), also promoted gender dominance of men over women in the pri-

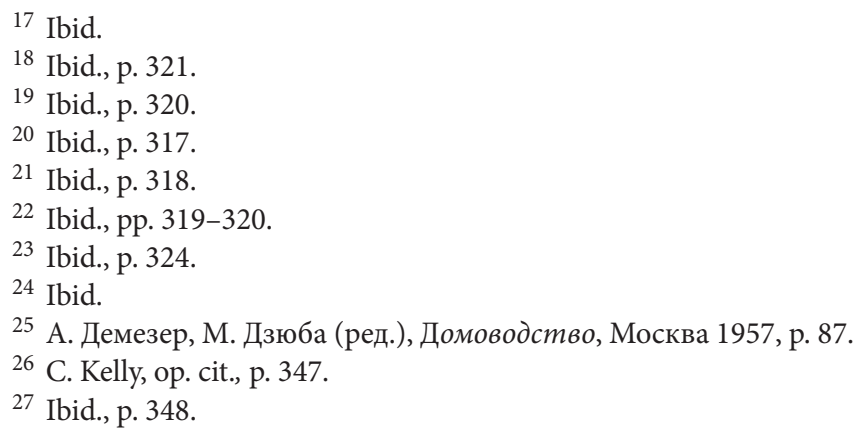


vate sphere. ${ }^{28}$ Young women were supposed to be taught to understand their roles of mothers and by being wives and mothers take "responsibility for the human race."29 This gender differentiation may be attributed to several factors, such as the demographic crisis in the Brezhnev era and the breakdown of the Soviet family, the assumed consequence of the erosion of traditional gender roles. ${ }^{30}$ Moreover, the fear of the 'emasculation' of Soviet men was becoming widespread. ${ }^{31}$ Men were kept away from housework and there were only a few books for men, which differed from those for women. The only handbook for boys and young men, called Advice to the Soldier, taught readers to change underwear and take a bath once a week. ${ }^{32}$ An interesting exception was A Thousand Hints To Your Health, a 1971 manual which included a controversial section on "manly cosmetics" - believed to be not masculine. ${ }^{33}$ In the Soviet Union, boys were not supposed to choose their own models of masculinity because only one was allowed. The real Soviet man could only be a labourer or a soldier who was supposed to achieve his manhood - synonymous with physical strength - by working hard and by keeping a family he could work hard for.

Soviet authors produced no separate books for boys and girls because "the child" was supposed to be a universal, unisex figure. ${ }^{34}$ Nonetheless, there were some books for young readers (school children aged 12-18), such as Dmitry Likhachev's Letters on Goodness and Beauty which included various information for children, including chapters on art, morality and the importance of "being like intelligentsia." 35 Children were taught about behaviour through poetry and fiction, for example in Samuil Marshak's poem If You're Polite (1953) readers learn to stand up for old people and use only normative vocabulary. ${ }^{36}$ Authors of many children's books, such as Lev Kassil, feared the non-Soviet culture and the Western ideas penetrating young people's minds through popular culture. ${ }^{37}$ Interestingly, the fear of using popular culture in texts for children can still be observed among teachers and researchers, however, for different reasons. ${ }^{38}$ The lack of popular culture may be attributed to the

28 В.А. Сысенко, Супружеские конфликты, Москва 1989, pp. 85-88.

29 В. Сухомлинский, Рождение гражданина, Москва 1971, p. 75.

${ }^{30}$ See L. Antwood, The New Soviet Man and Woman: Sex Role Socialization in the USSR, Basingstoke 1990.

${ }^{31}$ Ibid.

32 Я. Файншмидт (ред.), Полезные советы воину, Москва 1975, р. 397.

33 И. Кольгуненко, “Красота Кожи”, [в:] З. Коларова-Бирюкова (ред.), Тысяча советов «на здоровье», Москва 1971, pр. 171-173.

${ }^{34}$ See L. Rudova, “»Who’s the fairest of them all?« Beauty and Femininity in Contemporary Russian Adolescent Girl Fiction,” The Russian Review July 2014, 73, pp. 389-403.

35 Д. Лихачев, Письма о добром и прекрасном, Москва 1988, р. 17.

36 С. Маршак, “Ежели вы вежливы," Литературная газета 1953, № 26, 28 февраля.

${ }^{37}$ C. Kelly, op. cit., p. 341.

38 According to Buckingham, "it is possible to regard teaching about popular culture as an extension of progressivism. From this perspective, popular culture is seen as an authentic part of students' experience, and hence as something teachers should seek to validate and even to celebrate" (D. Buckingham (eds.), Teaching Popular Culture: Beyond Radical Pedagogy, London 1998, p. 8). Moreover, J. Marsh, 
fact that advice literature, which was successful with adults, did not become popular with children and adolescents. The omnipresent anti-Western ideas, the lack of references to popular culture and things popular with Soviet youth made these manuals popular with parents and teachers, but not children.

\section{Real Boys and Real Girls}

After the collapse of communism, the Ukrainian book market, previously dominated by books in Russian, started to change. Nowadays young readers can find books presenting different ideological discourses, as well as completely new forms of literature, such as e-books and book apps. Even though advice literature for children written in Ukrainian began to appear only in the early 2000s ${ }^{39}$ Advice literature for children written in Ukrainian quickly became popular and now most bookstores have a special section devoted to manuals, which usually come in set - pink for girls and blue for boys. While at first their contents seem to differ from each other, they all reinforce gender stereotypes.

Both A 100\% Girl and A 100\% Boy were edited and illustrated by Evhenia Zhytnyk and published by Shkola (A 100\% Girl was co-edited by Natalia Zotova and A $100 \%$ Boy by Oleksandr Zotov $\left.{ }^{40}\right)$. These handbooks for pre-teens represent a more Western-like model of advice literature than books from the early 2000s, such as Tetyana Shcherbachenko's A Little Lady. A Handbook for the $21^{\text {st }}$ Century Girl (2006), in which their author introduces new topics and pays much less attention to housekeeping and cooking. ${ }^{41}$ Despite the fact that both books look familiar, gender differentiation begins with their covers. The one for boys is blue and includes a picture of two boys in baggy jeans with a football and the guitar. The one for girls is pink and

E. Millard observe that "it is difficult to identify any work which suggests that teachers should unquestioningly celebrate children's popular culture in the classroom and use it as a liberating force. Thus, in any exploration of the relationship adults have to children's popular culture, we need to acknowledge that complex and contradictory strands are at work." J. Marsh, E. Millard, Literacy and Popular Culture. Using children's culture in the classroom, London, p. 33. See also V. Walkerdine, "Violent boys and precocious girls: regulating childhood at the end of the millennium," Contemporary Issues in Early Childhood 1999, vol. 1, no. 1, pp. 3-22; A. McRobbie, Postmodernism and Popular Culture, London 1994.

${ }^{39}$ More than ten books were published in the early 2000s, such as Н.М. Волчек, Енциклопедія для дівчат, Київ 2001, 2004, 2005; I. Гончаренко, Енциклопедія для юних леді, Харків 2002; Ю. Полякова, Сучасна енциклопедія для дівчаток, Донецьк 2003; А. Снєгірьова, Енциклопедія для дівчат: Перше кохання, Київ 2003; М.О. Хаткіна, Улюблена енциклопедія для дівчаток, Донецьк 2004; О.Я. Кривич, Енциклопедія для дівчаток, Харків 2006; М.О. Хаткіна, Чудова енциклопедія для сучасних дівчаток: 1000 відповідей на непрості запитання, Донецьк 2006; Є.Т. Братчина, Усе для дівчаток: Дитяча енциклопедія, Харків 2006; Г.Д. Швець, Енциклопедія домачніх справ для дівчаток, Київ 2007.

40 Є. Житник, Дівчинка на 100\%, Харків 2016; Є. Житник, Хлопчик на всі 100\%, Харків 2016.

41 See: M. Świetlicki, "You are not a doll, not a commodity! - Contemporary Ukrainian Advice Literature for Girls", Slavia Occidentalis 73/2, 2016, pp. 123-132. 
shows a blond-haired girl in a very short skirt and a navel revealing tank top, with a little dog on a leash. Even though the layout is quite similar, the changes are significant: girls should focus on looks, boys on play and social skills.

A 100\% Girl starts with a very chaotic chapter about health, skin care, hair removal, breasts, menstruation, and the first appointment with the gynaecologist. Additionally, it includes fragments about sport, diet, and eating disorders (40 pages). In the following chapter, the author focuses solely on beauty tips and fashion trends (20 pages), then she moves on to certain spare time activities (for instance traveling, dancing, reading, but also outdoor activities -32 pages) and relationships with parents and friends (including a fragment about divorce and adoption -26 pages). Zhytnyk pays particular attention to relationships with boys and underlines the differences between men and women, especially in sub-chapters titled "what type of girls boys like," "how not to lose him," and how to use "body language." Here girls learn about birth control and sex, the author states that girls should always be capable of saying no, STDs, HIV/AIDS, teenage pregnancy, and abortion (20 pages). Just like in previous Ukrainian manuals, there is no mention of non-heteronormative identities. The author then introduces more traditional subjects, such as preparing for holidays and celebrations (20 pages); etiquette and good manners (18 pages); housework and some cooking (27 pages); pets (11 pages); as well as dealing with emotions (34 pages). In the penultimate chapter Zhytnyk focuses on problematic issues such as drugs, cigarettes, alcoholism, child pornography, and once again the hazards of sex, HIV, and STDs (34 pages). In the last chapter, she discusses horoscopes and beliefs, a topic present in most Ukrainian manuals for girls and absent from books for boys (31 pages).

Even if at first glance $A 100 \%$ Boy is very similar, it significantly differs. The first chapter is less chaotic but also devoted to health, boys learn about the importance of exercise, a well-balanced diet, and some issues concerning puberty (51 pages). The second one is about hobbies. It is much longer (43 pages) and more interesting than the one for girls; here boys are introduced to martial arts and the importance of reading. The next chapters talk about pets (17 pages) and holidays (17 pages) unlike girls, boys are not taught to prepare traditional dishes. The following three chapters are more problematic. In Get to know yourself (33), Zhytnyk writes about emotions, personalities, and the meaning of names, in Friends (171-200) about the relationships with parents and male friendships. In A Girl - secrets of the alien creature (13 pages) she focuses on the natural differences between men and women, showing readers that men are discoverers and inventors and that they have created almost everything, even things usually associated with womanhood, such as weaving - "when men got bored of it, women started to take care of it," the author says (201). In the same chapter, boys learn how to make girls like them. They are supposed to pull their hair and tease them - then girls know that boys really care about them. Zhytnyk focuses on the differences between brains, girls are better students only because of the school system which discriminates against boys. Boys read that there 
are no men at schools and kindergartens (no "real" men work there - things like this can only be seen in the movies). Moreover, they learn that girls do not like weak boys with no muscles and geeks. In order to impress a girl, one has to be strong and sporty. When boys struggle with emotions, they cannot keep a diary because it is only for girls who are moody and constantly change their minds and opinions. Girls also love gossip and always pretend to be stupid because only then do boys like them. Unlike boys, girls wear tights and uncomfortable clothes in order to make boys like them. Even though in the same chapter some important issues are introduced, for instance STDs and HIV/AIDS, the part about teenage pregnancy is completely omitted, probably because it is believed to be a girl's problem. In the book for girls, the role of the father is also absent while discussing pregnancy. In the next two chapters Zhytnyk talks about etiquette; there is a useful fragment about table manners (31) and housework (17). Here, boys learn to tidy their rooms and be able to do other types of housework, such as ironing and cooking, a theme absent in earlier books. The same chapter includes a section on the importance of the first job and saving money. The next one is also thought-provoking. Devoted to addictions, it is quite different than the one for girls (19). It does not start with a fragment about the importance of tolerance. There is nothing about stealing or blackmailing. Unlike boys, girls are taught to control themselves and constantly beware of men who can hurt them. On the other hand, boys are only told to beware of fake news and to be able to distinguish between what is real and what is fake, as well as the dangers of the internet and video games, which can lead to serious addiction. On the one hand, boys learn to be able to control their anger; on the other, they are taught the importance of fighting back and protecting oneself. In this book, there is no mention of horoscopes and beauty products, issues found in all manuals for girls.

A 100\% Girl and A 100\% Boy promote less traditional gender roles than those present in books published in the 1990s and 2000s. Even though their author introduces problematic issues concerning sex, she reinforces differences between men and women, promoting the idea that women should prioritize looks and family life and men strength and career. In the book for girls, there are constant mentions of the importance of being safe and the dangers posed by boys, girls learn that they are not supposed to stay alone with boys: "Use your brains, behave in a graceful and modest way, you want men to respect you!" (142) Boys are not taught that they should always respect a girl's choice, but girls are supposed to always beware of boys. Both books reinforce the opinion that sometimes girls "ask for rape" and that certain clothes choices are to blame for the assault.

In 2016 the publishing house Gloria released two new manuals for children written by unknown authors: Encyclopaedia for Girls and Encyclopaedia for Boys. ${ }^{42}$ Even though their titles suggest similarity with Soviet books and Ukrainian Encyclopaedias from the early 2000s, both are not real encyclopaedias but rather short handbooks (128 pages). Their covers are also quite similar, the main difference being

${ }^{42}$ Енцииклопедія для дівчаток, Київ 2016; Енциклопедія для хлопчиків, Київ 2016. 
the colour, and the list of things included on the cover: the blue book for boys is about health, sport, school, hobbies, friends, etiquette, the pink one for girls is about beauty, health, hobbies, friends, sport, fashion, and school. This is significant, as it stresses the importance of beauty for girls and sport for boys. Encyclopaedia for Girls consists of nine chapters - "You are the best" (18 pages), "Real friends" (12 pages), "Young housewife" (20 pages), "Young fashionista" (14 pages), "Etiquette" (12 pages), "You-a student" (14 pages), "Your hobbies" (12 pages), "Safety" (10 pages) and "You're all grown-up!" (14 pages) - Encyclopaedia for Boys of only five - "It's great to be healthy!" (25 pages), "Sport in your life" (27 pages), "The world of your hobbies", (36 pages), "Pets" (15 pages), and the last one titled "Neither an adult, nor a child..." (16 pages). Both books include many colourful photographs, including pictures of celebrities.

The authors of Encyclopaedia for Girls focus on beauty, cooking, household chores, as well as etiquette, free time activities, first aid, and security at home and school. Even though most of the book is quite traditional, it includes two gripping chapters, "Real friends" and "You're all grown up!" In the first one girls learn that some boys like to bully girls when they want to impress them and that girls should always ignore them - only then is a real friendship with boys possible. "You're all grown up!" includes subchapters on horoscopes, love and infatuation. Here the authors list "things a boy who really likes you says" and "things a boy who wants to take advantage of you says" and talk about the hazards of sex, like HIV/AIDS (referred to as "the plague") and pregnancy. Early pregnancy is described as extremely dangerous for a girl's health. The authors provide readers with some information on abortion, which according to them, causes infertility and seriously damages health. Still, they state that single parenthood takes away a girl's chance of going to college or finding a good job because young mothers are bullied and consequently become socially alienated (121).

In Encyclopaedia for Boys, readers learn about the benefits of a well-balanced diet, there is information about vitamins and minerals, as well as tips on hygiene, acne, shaving, and choosing the right glasses. They are introduced to different types of sports and are encouraged to take them up. Hobbies for boys are significantly different than the ones promoted in the book for girls. Instead of cooking and knitting, they learn about traveling, camping, fishing, and collecting different things. The last chapter titled "Neither an adult, nor a child" is a hybrid of various manuals, including information about puberty and the differences between boys and girls, the code of a modern man - which is quite similar to the one found in Soviet military books etiquette, problems with siblings, school, addictions, extreme situations, looks (2 pages on clothes and style), first love and first kiss. There is no mention of sex, AIDS, pregnancy, contraception, abortion, fatherhood, but also of beauty and horoscopes.

Even though both Encyclopaedias contain some useful information, they reinforce patriarchy, promote gender stereotypes, and stigmatize sex and teenage pre- 
gnancy. Moreover, boys do not learn about the responsibility of having unprotected sex. Birth control, pregnancy, and abortion are all referred to as "a girl's problems."

\section{Conclusions}

In her thought-provoking speech Chimamanda Ngozi Adichie asks "why we don't teach boys the same?" The analysis of Ukrainian handbooks for boys and girls leaves readers with the same question. Contemporary advice literature not only promotes inequality and can be harmful for girls, but it is also hurtful for boys, as it reinforces singular versions of femininity and masculinity. Girls learn to "shrink themselves, to make themselves smaller" because housework and family life are most important. Advice literature teaches them that their options are limited - "You should aim to be successful, but not too successful." - and that even though they should aspire to marriage, when it comes to pregnancy, they cannot depend on men. Still, they should do everything to be physically attractive in order to please men. Boys, on the other hand, are taught that they should not express their emotions, play and talk with girls, and even though they are supposed to be strong individuals, they can be themselves as long as they are not wimps. Even though getting rid of all of the gender stereotypes in advice literature is difficult, I would like to argue that Ukrainian writers should start with writing books that both boys and girls can read. Instead of promoting only pink and blue books filled with stereotypes, Ukrainian publishing houses could think of publishing colourful manuals for children of both sexes.

\section{Bibliography}

Antwood, L. (1990). The New Soviet Man and Woman: Sex Role Socialization in the USSR, Basingstoke 1990.

Bourdieu, P. (1979) "Symbolic power," Critique of Anthropology, vol. 4, pp. 77-85.

Brannon, R. (1976) "The male sex role: Our culture's blueprint for manhood and what it's done for us lately," In The Forty-Nine Percent Majority: The Male Sex Role, ed. D. David, R. Brannon, Reading MA, pp. 1-48.

Buckingham, D. (ed.) (1998) Teaching Popular Culture: Beyond Radical Pedagogy, London, UCL Press.

Buckingham, D. and Sefton-Green, J. (1994) Cultural Studies Goes to School: Reading and Teaching Popular Media, London, Taylor and Francis.

Bureychak, T. (2008) "Crisis of masculinity in theoretical and Eempiric perspectives," In Gender Theories, Gender Practices: Building Bridges, Kharviv, pp. 20-27.

Chimamanda, N.A, We should all be feminists, https://www.youtube.com/watch?v=hg3umXU_qWc (access: 15.07.2017).

Connell, R.W., Messerschmidt, J.W. Hegemonic Masculinity: Rethinking the Concept, "Gender \& Society," (December) 2005, vol. 19, no. 6, pp. 829-859. 
Davies, B. (1990) "Agency as a form of discursive practice: A classroom scene observed," British Journal of Sociology of Education, vol. 11, no. 3, pp. 341-61.

Davies, B. (1992) “The gender trap: a feminist post-structuralist analysis of primary school children's talk about gender," Journal of Curriculum Studies, vol. 24, no. 1, pp. 1-25.

Davies, B. (1997) "Constructing and deconstructing masculinities through critical literacy," Gender in Education, vol. 9, no. 1, pp. 9-30.

Francis, B. (1998) Power Plays: Primary School Children's Constructions of Gender, Power and Adult Work, Stoke-on-Trent, Trentham Books.

Jordan, E. (1995) "Fighting boys and fantasy play: the construction of masculinity in the early years of school," Gender and Education, vol. 7, no. 1, pp. 69-86.

Kaganovsky, L. (2008) How the Soviet Man Was Unmade: Cultural Fantasy and Male Subjectivity under Stalin, Pittsburgh.

Kelly, C. (2001) Refining Russia: Advice Literature, Polite Culture, and Gender from Catherine to Yeltsin, Oxford, p. 374.

Kidd, K. B. (2004) Making American Boys: Boyology and the Feral Tale, Minneapolis-London.

Lanoux, A. (2004) "Laundry, potatoes, and the everlasting soul: Russian advice literature for girls after communism," The Russian Review 73 July, p. 405.

Mac an Ghaill, M. (1994) The Making of Men: Masculinities, Sexualities and Schooling, Buckingham, Open University Press.

MacNaughton, G. (1997) "Who's got the power? Rethinking gender equity strategies in early childhood," International Journal of Early Years Education, vol. 5, no. 1, pp. 57-66.

Marsh J., Millard, E. (2000) Literacy and Popular Culture. Using children's culture in the classroom, London, Paul Chapman Publishing Ltd.

McRobbie, A. (1994) Postmodernism and Popular Culture, London, Routledge.

Millard, E. (1997) Differently Literate: The Schooling of Boys and Girls, London, Falmer Press.

Novikova, I. (2000) “Soviet and post-Soviet masculinities: After men's wars in women's memories," In Male roles, masculinities and violence: a culture of peace perspective, eds. I. Breines, R. Connell, and I. Eide, UNESCO publishing, Paris, pp. 117-130.

Solsken, J. (1993) Literacy, Gender, and Work in Families and in School, Norwood, NJ, Ablex.

Świetlicki, M. (2016) "You are not a doll, not a commodity! — Contemporary Ukrainian Advice Literature for Girls", Slavia Occidentalis 73/2, pp. 123-132.

Thorne, B. (1993) Gender Play: Girls and Boys in School, Buckingham, Open University Press.

Walkerdine, V. (1999) "Violent boys and precocious girls: regulating childhood at the end of the millennium," Contemporary Issues in Early Childhood, vol. 1, no. 1, pp. 3-22.

Weedon, C. (1987) Feminist Practice and Poststructuralist Theory, Oxford, Blackwell.

Whyte, J. (1983) Beyond the Wendy House: Sex Role Stereotyping in Primary Schools, York, Longman for the Schools Council.

Демезер, А., Дзюба, М. (ред.). (1957) Домоводство, Москва, Государственное издательство сельскохозяйственной литературы.

Енциклопедія для дівчаток (2016) Київ, Глорія.

Енциклопедія для хлопчиків, (2016) Київ, Глорія.

Житник, Є. (2016) Дівчинка на 100\%, Харків, Школа.

Житник, Є. (2016) Хлопчик на всі 100\%, Харків, Школа.

Кольгуненко, И. (1971) “Красота Кожи,” [в:] 3. Коларова-Бирюкова (ред.), Тысяяча советов «на здоровье», Москва Советская Россия, рp. 171-173.

Лихачев, Д. (1988) Письма о добром и прекрасном, Москва, Детская литература.

Маршак, С. (1953) “Ежели вы вежливы," Литературная Газета 1953, № 26, 28 февраля.

Сухомлинский, В. (1971) Рождение гражданина, Москва, Молодая гвардия.

Сысенко, В.А. (1989) Супружеские конфликты, Москва, Мысль.

Файншмидт, Я. (ред.), (1975) Полезные советы воину, Москва: Воениздат.

Miscellanea Posttotalitariana Wratislaviensia 7, 2017

(C) for this edition by CNS 
Чернова, Ж., “Модель «советского» отцовства: дискурсивные предписания,” [в:] Е. Здравомыслова, А. Темкина (ред.), Российский гендерный порядок: социологический поход: Коллективная монография, Санкт-Петербург 2007, pp. 138-168.

Accepted for publication: 10.10.2017 